\title{
AVAILABILITY AND UTILIZATION OF LABORATORY FACILITIES IN PATIENT MANAGEMENT: A STUDY AT A TERTIARY CARE HOSPITAL OF NORTH EAST INDIA
}

ABSTRACT The direct impact of diseases on the population reinforces the recognition that disease prevention and control are critical to sustainable human development. Laboratory test utilization management is the latest expression of a long trend in healthcare to control costs and improve quality. The study is designed to find out the availability and utilization of laboratory facilities in patient management along with availability of Laboratory infrastructure with use-coefficient of equipment and their implication on patient care services. Utilization of laboratory investigation revealed an increase in the number of tests during a particular month due to high patient load. Yearly utilization of laboratory investigations may follow a different trend in the utilization of laboratory tests. In this study major equipment shows user coefficient 50 or more with highest of 75 .This study suggested the need of extensive study with longer period to analyze and formulate policies for effective utilization of equipment and laboratory infrastructure.

\section{KEYWORDS : Laboratory, Investigation, Use-coefficient}

\section{INTRODUCTION:}

The efficient operation of a Clinical Laboratory and the effective delivery of medical Laboratory services to clinicians and their patients require a complex interdigitation of expertise in medical, scientific and technical areas. Over the years the practice of medicine and surgery has become increasingly complex and so have the demands that are placed on laboratories. The direct impact of diseases on the population reinforces the recognition that disease prevention and control are critical to sustainable human development. Utilization of Laboratory services has increased during the last several decades in many health care jurisdictions ${ }^{1}$.The bridge between the basic science and Clinical Medicine is buttressed by essential support derived from equipment, reagents, computer, management technique and quality assurance approaches provided by industry ${ }^{2}$. Interventions to improve laboratory utilization include physician's education, laboratory requisition form changes; and policies concerning laboratory test ordering studies have concluded that educational interventions have mixed effects on laboratory test use ${ }^{3}$.However, the term medical equipment excludes implantable, disposable, or single-use medical devices, explains WHO medical device technical series ${ }^{4}$.The introduction of state of the art technology has resulted in metamorphic changes in diagnostic and therapeutic modalities in patient care activities. This has lead to enhancement of quality of life and deceased morbidity and mortality rates. However, modern medical technology is not panacea for all ills. The adverse effects include supplier induced demands, indiscriminate use, duplication and underutilization ${ }^{5}$. The discipline of Laboratory medicine can be viewed as a bridging endeavor linking the basic medical, biological, and physical science with medical practices. Over the years the practice of medicine and surgery has become increasingly complex and so have the demands that are placed on laboratories.

\section{MATERIAL AND METHODS:}

Present study was carried out in a tertiary care health Institute of North East India during the month of september-November 2019. It caters diagnostic service for both outpatients and inpatient departments. The institute has laboratories which include Clinical Biochemistry, Microbiology including Parasitological, bacteriological, mycology, serology and Clinical pathology.

The study was exploratory and observational in nature and was designed to achieve all objectives of the study work.

(a) Observational Study included daily collection of data regarding workload in the central Laboratory by direct observation. Use coefficient is used to assess the utilization of commonly used equipment.

(b) The data obtained through the observational study was supplemented and cross checked with the daily records, requisition slips/registers/report register etc. maintained in the central Laboratory as well as other medical records of other related departments.

This study also includes availability of Laboratory infrastructure in terms of equipment and their implication on patient care services. Use coefficient is used to assess the utilization of commonly used equipment i.e whether the equipment is optimally utilized or underutilized. It provides a sight on Effective Demand (Utilization) of Laboratory Services for better planning.

\section{RESULTS}

Data are collected from daily collection of data regarding workload in the central Laboratory by direct observation with the data obtained through the observational study, which was supplemented and cross checked with the daily records, requisition slips/registers/report register etc. maintained in the central Laboratory as well as other medical records of other related departments. Use Coefficient of Commonly used Equipments also calculated in this study.

Table l: Patient And Department Wise Total Test

\begin{tabular}{|l|l|l|l|l|l|}
\hline $\begin{array}{l}\text { Month and } \\
\text { Year }\end{array}$ & $\begin{array}{l}\text { Total } \\
\text { No. of } \\
\text { Patien } \\
\text { ts }\end{array}$ & $\begin{array}{l}\text { Patholo } \\
\text { gical } \\
\text { test }\end{array}$ & $\begin{array}{l}\text { Microbiolog } \\
\text { ical test }\end{array}$ & $\begin{array}{l}\text { Biochemi } \\
\text { stry test }\end{array}$ & $\begin{array}{l}\text { Total } \\
\text { No of } \\
\text { Test }\end{array}$ \\
\hline $\begin{array}{l}\text { September } \\
\text { August 2019 }\end{array}$ & 11436 & 2500 & 2485 & 3100 & 8085 \\
\hline $\begin{array}{l}\text { October } \\
2019\end{array}$ & 10642 & 2470 & 2376 & 2920 & 7766 \\
\hline $\begin{array}{l}\text { November } \\
2019\end{array}$ & 11282 & 2567 & 2380 & 3120 & 8067 \\
\hline
\end{tabular}

Table 2: List Of Major Equipments

\begin{tabular}{|l|l|l|}
\hline $\begin{array}{l}\text { SL } \\
\text { NO }\end{array}$ & NAME OF EQUIPMENTS & QTY. \\
\hline 1. & Clinical laboratory urine analyser & 01 NOS \\
\hline 2. & Multi parameter immunology analyzer & 02 NOS \\
\hline 3. & Fully Automated Haematology Analyser & 02 NOS \\
\hline 4. & QBC System. & 01 NOS \\
\hline 5. & Double Beam Spectrophotometer. & 01 NOS \\
\hline 6. & Digital Microscope & 01 NOS \\
\hline 7. & ELISA System. & 02 NOS \\
\hline
\end{tabular}

GJRA - GLOBAL JOURNAL FOR RESEARCH ANALYSIS 45 


\begin{tabular}{|l|l|l|}
\hline 8. & Rotary Microtome & 01 NOS \\
\hline 9. & Tissue Floatation Bath & 01 NOS \\
\hline 10. & Fully automated clinical chemistry analyzer & 02 NOS \\
\hline 11. & Electrolyte analyzer & 01 NOS \\
\hline
\end{tabular}

\section{USE COEFFICIENT:}

This coefficient is applied to assess the utilization of an equipment i.e whether the equipment is optimally utilized or underutilized. Additional demands of the equipment may be assessed by use of the formula

Use coefficient $=\mathrm{N} / \mathrm{M} \times 100$

Where,

$\mathrm{N}=$ Average number of hours the equipment is used per day

$\mathrm{M}=$ Maximum number of hours the equipment can be used per day

Table 3: Use Coefficient Of Commonly Used Equipments

\begin{tabular}{|l|l|l|l|l|}
\hline $\begin{array}{l}\text { SL } \\
\text { NO }\end{array}$ & NAME OF EQUIPMENTS & $\begin{array}{l}\text { N } \\
\text { In } \\
\text { Hrs }\end{array}$ & $\begin{array}{l}\text { M } \\
\text { In }\end{array}$ & $\begin{array}{l}\text { Use } \\
\text { Coefficient }\end{array}$ \\
N/M x 100 \\
\hline 1 & $\begin{array}{l}\text { Fully automated clinical } \\
\text { chemistry analyzer }\end{array}$ & 06 & 12 & 50 \\
\hline 2 & $\begin{array}{l}\text { Multi parameter immunology } \\
\text { analyzer }\end{array}$ & 06 & 10 & 60 \\
\hline 3 & $\begin{array}{l}\text { Fully Automated Haematology } \\
\text { Analyser }\end{array}$ & 06 & 08 & 75 \\
\hline 4 & Electrolyte analyzer & 05 & 08 & 62.5 \\
\hline
\end{tabular}

If the use-coefficient is less than $50 \%$, it is considered to be underutilized and hence a bad investment. However, life saving equipment cannot be subjected to this kind of assessment. In this study major equipment shows user coefficient 50 or more.

Total number of Patient during this study period is 33,360 . Study revealed a total of 23918 investigations were analyzed in the Laboratory as shown in Table l.The month wise distribution of the test performed showed an increase in the number of tests during the month of September. List of equipment is shown in Table 2.Use Coefficient of Commonly used Equipments shown in table 3 with highest of 75 for the equipment Fully Automated Hematology Analyzer. Other equipment also shows use coefficient of 50 or more.

\section{DISCUSSION:}

This study revealed that a total of 23918 investigations were ordered for the period of study amongst 33,360 patients. Utilization of laboratory investigation revealed an increase in the number of tests during a particular month due to high patient load. Yearly utilization of laboratory investigations may follow a different trend in the utilization of laboratory tests. This study revealed that total of 23918 laboratory tests were performed for the period of study with highest total in the month of september.In use-coefficient of equipment study; if the use-coefficient is less than $50 \%$, it is considered to be underutilized and hence a bad investment. However, life saving equipment cannot be subjected to this kind of assessment. In this study major equipment shows user coefficient 50 or more with highest of 75 .

The increasing costs of medical care mandate that those in Clinical laboratories and their Clinical colleagues be concerned as well with effective utilization of Laboratory services in medical care. Utilization of services or actual courage is expressed as the proportion of people in need of a service who actually receive it in a given period, usually a year. But in this study, we collect the data only for three month which is one of the limitations of this study. Today hospitals employ a wider range of multidisciplinary professionals, are more densely packed with technology, and house more variety of technology than ever before in patient care activities.
Hospital, have limited resources that must be utilized in the most efficient means possible. Because utilization management of laboratory tests is now a high priority at most clinical laboratory and requires this type of study for need assessment and proper utilization of services. By collecting baseline information and comparing it to a desired standard, the existing gap can be identified.

\section{SUMMARY AND CONCLUSION:}

Utilization management of laboratory tests is now a high priority at most clinical laboratory as all organizations, whether Govt or private, have limited resources that must be utilized in the most efficient means possible. The increasing costs of medical care mandate that those in Clinical laboratories and their Clinical colleagues be concerned as well with effective utilization of Laboratory services in medical care. Need assessment and proper utilization of services by collecting baseline information and comparing it to a desired standard, the existing gap can be identified. The importance of good advanced planning must never be underestimated as it provides critical information management requires allocating resources that will enable the organization to reach its objectives.

The direct impact of diseases on the population reinforces the recognition that disease prevention and control are critical to sustainable human development. Laboratory test utilization management is the latest expression of a long trend in healthcare to control costs and improve quality. The study is designed to find out the availability and utilization of laboratory facilities in patient management along with availability of Laboratory infrastructure with use-coefficient of equipment and their implication on patient care services. There was a progressive increase in quantum of tests ordered for the period of study. Utilization of laboratory investigation revealed an increase in the number of tests during a particular month due to high patient load. Yearly utilization of laboratory investigations may follow a different trend in the utilization of laboratory tests. In this study major equipment shows use coefficient 50 or more. If the use-coefficient is less than $50 \%$, it is considered to be underutilized and hence a bad investment. However, life saving equipment cannot be subjected to this kind of assessment.

Utilization of services or actual courage is expressed as the proportion of people in need of a service who actually receive it in a given period, usually a year. The needs assessment process is a powerful tool for determining medical device needs at the facility, regional and/ or country level. There are some tests that have traditionally been underutilized and also there are tests where the appropriate level of utilization is unclear or controversial. Laboratory services are required to find out its utilization and patient care management by collecting baseline information and comparing it to a desired standard. But in this study, we collect the data only for three month which is one of the limitations of this study. It requires an extensive study with longer period to analyze the whole study to develop a strategic framework.

\section{Acknowledgement}

The authors acknowledge and appreciate all contributors directly or indirectly related to the study.

\section{Conflicts Of Interest}

There are no conflicts of interest.

\section{REFERENCES}

1. Leese B; Is there too much laboratory testing?York, England: University of York; 1991: 70.

2. Martin Betting G, Ben Moore, McClendon WilliamW; Organization and Management of the clinicallaboratory: Clinical Diagnosis and Management byLaboratory Methods, 18th Edition, 1991: 1307-11.

3. Kathryn T. Hayward Donald, McLendon William W: Financial Management of the Clinical Laboratory. Clinical diagnosis and management by laboratory 
methods, 18th edition 1991: 1321

4. WHO. Medical Device Technical Series: Introduction to Medical Diagnostic

Equipment Inventory Management. Geneva:WHO; 2011. Available from:

http://www.whqlibdoc.who.int/publications/2011/9789241501392_eng.pdf. [Last accessed on 2013 Aug 09].

5. Introduction of Management-II, Essentials of Logistics and Equipment Management.New delhi, IGNOU, School of Health Sciences 